\title{
SUSCEPTIBILITY OF NASUTITERMES EHRHARDTI (ISOPTERA: TERMITIDAE) TO BACILLUS THURINGIENSIS SUBSPECIES
}

\author{
Raquel de Castilhos-Fortes ${ }^{1 *}$; Aida T.S. Matsumura² ${ }^{2}$ Elena Diehl$^{3}$; Lidia M. Fiuza ${ }^{1}$ \\ ${ }^{1}$ Laboratório de Microbiologia, UNISINOS. São Leopoldo, RS, Brasil; ${ }^{2}$ Departamento de Saúde Vegetal, Universidade Federal \\ do Rio Grande do Sul, Porto Alegre, RS; ${ }^{3}$ Laboratório de Genética, UNISINOS, São Leopoldo, RS, Brasil
}

Submitted: May 31, 2001; Returned to authors for corrections: August 03, 2001; Approved: August 30, 2002

\begin{abstract}
The effects of Bacillus thuringiensis (Bt) Berliner on the termite Nasutitermes ehrhardti (Isoptera, Termitidae) were evaluated under laboratory conditions. From $55 \mathrm{Bt}$ subspecies assayed in vivo under controlled conditions seven were found to be pathogenic in the subspecies yunnanensis, huazhongiensis, brasiliensis, colmeri and kurstaki (less than $72 \%$ of mortality), particularly sooncheon and roskildiensis (100\% mortality at the seventh day after the bacteria application). The $\mathrm{LC}_{50}$ for subspecie sooncheon corresponded to $47 \times 10^{8}$, $66.2 \times 10^{6}$ and $5.1 \times 10^{5} \mathrm{cells} / \mathrm{ml}$, at the third, fifth and seventh day, respectively. For the subspecie roskildiensis the $\mathrm{LC}_{50}$ corresponded to $30.8 \times 10^{5}, 48.4 \times 10^{6}$ and $16.8 \times 10^{4} \mathrm{cell} / \mathrm{ml}$, at the third, fifth and seventh day, respectively. The results show that the two most pathogenic subspecies effectively may be studied with regard to control the termite $N$. ehrhardti.
\end{abstract}

Key words: Bacillus thuringiensis, biological control, entomopathogenic bacteria, Nasutitermes ehrhardti, termite

\section{INTRODUCTION}

Termites, social insects present in almost all natural or disturbed warm terrestrial environments, feed on cellulose. Several species play significant ecological roles, recycling mineral nutrients in soil and participating in the regeneration of disturbed environments. However, several other species are responsible for great damage in forests, crops, pasture and buildings (6). The complexity of termite biology and behavior makes it hard to control them (14). The current control methods are expensive, limited on efficiency and environmentally harmful. Hence, it is necessary to search for alternative methods such as biological control, especially microbial control, to the manage termites populations (5).

Bacillus thuringiensis Berliner, 1915, (Bt) is currently responsible for most of the microbiological control of pest insects and is used world wide, as both biopesticides $(1,16)$ and in transgenic plant production $(9,10,17)$. This biological control agent is thus the most promising potential candidate to use against termites.

The largest collections of $\mathrm{Bt}$ strains belong to the Agriculture Department of the USA, and to private institutions such as Plant Genetic Systems, Mycogen and Ecogen (2) totalling approximately 40,000 Bt strains. The existence of 77 genes, that coding for the insecticidal crystal proteins, already characterized was reported by the Bacillus Genetic Stock Center in 1999. The new nomenclature of characterized genes coding for $\delta$-endotoxins of $B$. thuringiensis is presented by Crickmore et al. (7). However until now the identification of B. thuringiensis strains containing genes coding for proteins active against isopterans has not been reported.

The genus Nasutitermes (Termitidae, Nasutitermitinae) comprises more than 40 species, and it is very common in Brazil. This termite is found in all habitats and mainly feeds on wood products (4). The Nasutitermes ehrhardti builds hill-nests causing serious difficulties to crop management and it is an

\footnotetext{
* Corresponding author. Mailing address: Av. UNISINOS, 950, Caixa Postal 275. 93001-970, São Leopoldo, RS, Brasil. Tel.: (+5551) 590-3333 Ext. 1246. Fax: (+5551) 590-8122. E-mail address: raquelcf@cirrus.unisinos.br
} 
important pest of pasture and rice, corn, sugar-cane, peanut and eucalyptus crops. The present work aimed at evaluating Bacillus thuringiensis pathogenicity against $N$. ehrhardti. The entomopathogenic effect of 55 strains of this bacterium against the termite was evaluated by in vivo assays, initially in screening tests, then the two most pathogenic isolates were bioassayed more accurately.

\section{MATERIALS AND METHODS}

Termites used in the tests were collected from nests located in the campus of the university (29\%47'31' $S$; $51^{\circ} 09^{\prime} 07^{\prime}$ 'W) in the municipality of São Leopoldo and maintained under laboratory conditions. Strains of $B t$ used is the bioassays were obtained from the Laboratory of Entomophatogenic Bacteria of the Institute Pasteur, France (Appendix 1).

Isolates of Bt were grown on Glicosated Usual medium (8), at $28^{\circ} \mathrm{C}$ and $180 \mathrm{rpm}$. For each isolate, after bacterial lysis the mixture containing spores, crystals and vegetative cells was centrifuged at 5,000 rpm for $15 \mathrm{~min}$. The concentrate was diluted in phosphate buffer $\left(\mathrm{NaH}_{2} \mathrm{PO}_{4} \mathrm{H}_{2} \mathrm{O}, 0.1 \mathrm{M}\right) \mathrm{pH} 6.0$ added with PMSF (phenylmethylsulfonyl) and centrifuged again at 5,000 rpm for $15 \mathrm{~min}$. The pellet was suspended in phosphate buffer added with $\mathrm{NaCl} 0.1 \mathrm{M}$ and kept on ice for $5 \mathrm{~min}$. Then, it was centrifuged at 5,000 rpm, the pellet suspended in phosphate buffer $\mathrm{pH} 7.5$ and centrifuged at 5,000 rpm for 30 minutes. The obtained pellet was diluted in MILLI-Q $\mathrm{H}_{2} \mathrm{O}$.

Bioassays consisted of two steps. Initially, 55 strains were tested in pre-selective assays in order to select isolates against the termite $N$. ehrhardti. Then the $\mathrm{LC}_{50}$ was determined for the pathogenic strains. The suspensions from isolates of $B$. thuringiensis used in initial screening assays consisted of vegetative cells, spores and crystals. From each suspension 250 $\mu \mathrm{l}$ were applied to cellulose portions of $1 \mathrm{~cm}^{2}$, which were offered to the termites as food source. After evaporation of excess humidity, the cellulose portions were individually placed in acrylic plates with six chambers of $5.5 \mathrm{~cm}$ diameter. In each chamber ten insects were placed. Per treatment three chambers were used, totaling 30 insects for each isolate. As control distilled water was used instead of B. thuringiensis strains on cellulose portions.

Screening assays were kept in a Biological Oxygen Demand chamber, at $28^{\circ} \mathrm{C} \pm 1^{\circ} \mathrm{C}$, approximately $70 \% \mathrm{RH}$, in darkness. Insect mortality was recorded daily until the seventh day after the bioassay ouset.

For the $\mathrm{LC}_{50}$ determination of the isolates of $B$. thuringiensis subsp. sooncheon and subsp. roskildiensis the concentrations used were $10^{4}, 10^{5}, 10^{6}, 10^{7}$ and $10^{8}$ cells $/ \mathrm{ml}$, totaling six treatments, including the control. The method for treatment was the same as used in the screening assays, but each treatment consisted of 60 individuals, totaling 360 termites per isolate tested. The distribution and evaluation followed the same parameters described above.
Termites that died during bioassays were kept at $-18^{\circ} \mathrm{C}$ and were later individually crushed and observed under phase contrast microscopy in order to confirm the presence of $B$. thuringiensis in their digestive tract.

The results obtained from the different concentrations tested in vivo were analyzed using Median Lethal Time $\left(\mathrm{LT}_{50}\right)$ and Median Lethal Concentration $\left(\mathrm{LC}_{50}\right)$ obtained from Probit analysis (11).

\section{RESULTS AND DISCUSSION}

From the 55 strains of $B$. thuringiensis tested during screening assays against $N$. ehrhardti, seven were pathogenic as follows: B. thuringiensis subsp. sooncheon (Bts) and B. thuringiensis subsp. roskildiensis (Btr) with $100 \%$ of mortality, followed by B. thuringiensis subsp. yunnanensis (Bty) with $71.4 \%$, B. thuringiensis subsp. huazhongiensis (Bth) with $57.1 \%$, B. thuringiensis subsp. brasiliensis (Btb) with $52.3 \%$, B. thuringiensis subsp. colmeri (Btc) with $42.85 \%$ and B. thuringiensis subsp. kurstaki (Btk) with $28.57 \%$ of mortality at the seventh day after the treatment application.

References of Bacillus thuringiensis active against termites are scarce and there is little available data. The toxic effects of $B t$ against several termites species have been verified, but the subspecies which were used are not mentioned by the authors (6).

There is a group of many subspecies of $B$. thuringiensis active against lepidopterans $(3,12)$, and more restricted groups also against dipterans and coleopterans $(3,13)$. From the 52 subspecies of $B t$ tested against Spodoptera frugiperda (Lepidoptera, Noctuidae) by Hernandez (12), B. thuringiensis subsp. kurstaki was pathogenic, while B. thuringiensis subsp. colmeri presented a low activity against to this fall armyworm. However, our results show that the subspecies B. thuringiensis subsp. kurstaki and B. thuringiensis subsp. colmeri caused, respectively, $28.57 \%$ and $42.85 \%$ of mortality to $N$. ehrhardti.

Still considering the available data on the effects of $B$. thuringiensis against other insect orders, bioassays were conducted by Caetano et al. (3) with 41 B. thuringiensis strains against Anticarsia gemmatalis (Lepidoptera, Noctuidae), Spodoptera frugiperda and Tenebrio molitor (Coleoptera, Tenebrionidae), resulting in one isolate pathogenic to these three insects, four to A. gemmatalis and T. molitor, one to $S$. frugiperda and T. molitor, eight to A. gemmatalis, eight to $T$. molitor and one to $S$. frugiperda, while 18 did not cause mortality to the tested insects. These results show that there are wide differences in the specificity among isolates, also individual isolates are active against many different insect orders, including Isoptera. Our work has added another isopteran species susceptible to seven $B t$ subspecies. 
The isolates B. thuringiensis subsp. sooncheon and $B$. thuringiensis subsp. roskildiensis, which caused $100 \%$ mortality during the pre-selective assays, were used to determine the $\mathrm{LC}_{50}$. On the third, fifth and seventh days, the $\mathrm{LC}_{50}$ for $B$. thuringiensis subsp. sooncheon was achieved with suspensions bearing $4.70 \times 10^{9}, 6.62 \times 10^{7}$ and $5.14 \times 10^{5}$ cells $/ \mathrm{ml}$, respectively. For B. thuringiensis subsp. roskildiensis the $\mathrm{LC}_{50}$ was obtained with $3.08 \times 10^{6}, 4.84 \times 10^{7}$ and $1.68 \times 10^{5} \mathrm{cells} / \mathrm{ml}$, respectively (Table 1).

The Median Lethal Time (Table 2) for B. thuringiensis subsp. sooncheon and $B$. thuringiensis subsp. roskildiensis, varies according to the concentrations, being inversely proportional to the concentration. The time for the two subspecies are similar, but surprisingly the time for the increasing concentrations are not significantly different statistically due to the wide overlapping confidence intervals.

Khan et al. (15) isolated B. thuringiensis from naturally infected nymphs of the termite Bifiditermes beesoni, causing high mortality of Heterotermes indicola when the bacteria was used against it.

Thuricide-HP (Sandoz), B. thuringiensis subsp. kurstaki, was tested by Khan et al. (14) against Microcerotermes championi and $B$. beesoni to determine the mean lethal doses and times. The authors found differences in the mean lethal doses and time for these two termites, indicating differences in the specificity. The results, compared with those obtained in this study, indicate that the strains B. thuringiensis subsp. sooncheon and $B$. thuringiensis subsp. roskildiensis tested against $N$. ehrhardti were more pathogenic than $B$. thuringiensis subsp. kurstaki used against $M$. championi and B. beesoni. This is based on the suspension used by Khan et al. who emploied $1 \mathrm{ml}$ of $16 \times 10^{9}$ cells $/ \mathrm{ml}$, while in the maximum tested concentration against $N$. ehrhardti ( $1 \times 10^{8}$ cells $\left./ \mathrm{ml}\right)$ only $250 \mathrm{ml}$ were inoculated, while the median lethal time for this concentration were 4.23 days for $B$. thuringiensis subsp. sooncheon and 4.54 days for $B$. thuringiensis subsp. roskildiensis.

The pathogenicity of $B$. thuringiensis against $N$. ehrhardti was confirmed by presence of its cells under microscope observation of mixed termites guts, at the third, fifth and seventh days after the treatment application.
Table 2. Median Lethal Time $\left(\mathrm{LT}_{50}\right)$ of the termite Nasutitermes ehrhardti treated with Bacillus thuringiensis in laboratory.

\begin{tabular}{|c|c|c|c|c|}
\hline & $\begin{array}{l}\text { uspension }(1 \mathrm{x}) \\
(1 \mathrm{x}) \text { cells } / \mathrm{ml}\end{array}$ & $\begin{array}{l}\mathrm{LT}_{50} * \\
\text { (days) }\end{array}$ & $\begin{array}{c}\text { Confidence } \\
\text { interval (days) }\end{array}$ & Line equation \\
\hline & $10^{4}$ & 14.67 & $2.45-87.89$ & $Y=0.85 x+2.32$ \\
\hline & $10^{5}$ & 11.84 & $4.90-28.57$ & $Y=1.46 x+0.53$ \\
\hline & $10^{6}$ & 9.62 & $4.94-18.70$ & $\mathrm{Y}=1.54 \mathrm{x}+0.41$ \\
\hline & $10^{7}$ & 8.38 & $3.30-21.26$ & $\mathrm{Y}=0.9 \mathrm{x}+2.38$ \\
\hline & $10^{8}$ & 4.23 & $3.65 \quad 4.76$ & $Y=4.35 x+2.38$ \\
\hline & $10^{4}$ & 12.17 & $3.88-38.10$ & $y=1.14 x+1.48$ \\
\hline & $10^{5}$ & 6.79 & $4.42-10.45$ & $y=1.35 x+0.88$ \\
\hline & $10^{6}$ & 7.27 & $1.70-31.01$ & $y=0.47 x+3.64$ \\
\hline & $10^{7}$ & 6.80 & $4.42-10.44$ & $y=1.45 x+0.88$ \\
\hline $\begin{array}{ll}\overline{0} \\
\infty & \dot{0} \\
\overrightarrow{0} & 0\end{array}$ & $10^{8}$ & 4.54 & $1.07-5.00$ & $y=5.53 x-9.69$ \\
\hline
\end{tabular}

* 60 insects per treatment.

Figure 1. Mortality of the termite Nasutitermes ehrhardti caused by seven strains of Bacillus thuringiensis under laboratory conditions.

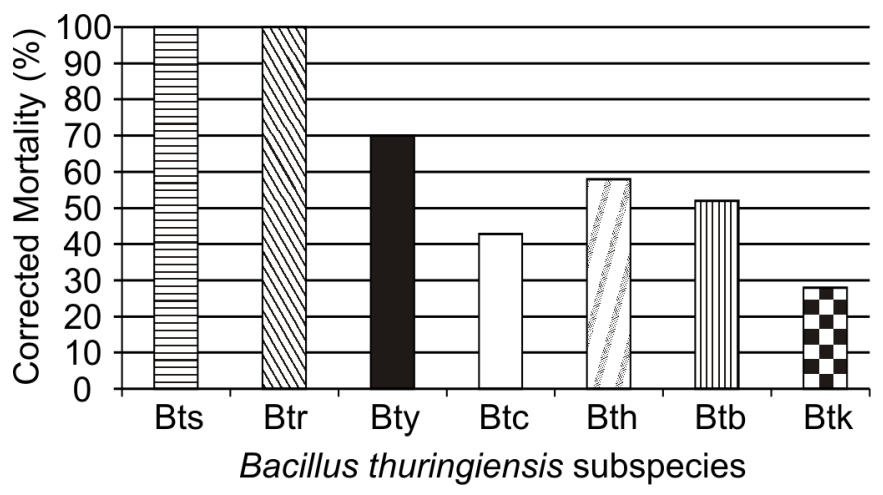

(Bts) B. thuringiensis subsp. sooncheon, (Btr) B. thuringiensis subsp. roskildiensis; (Bty) B. thuringiensis subsp. yunnanensis, (Btc) B. thuringiensis subsp. colmeri; (Bth) B. thuringiensis subsp. huazhongiensis, (Btb) B. thuringiensis subsp. brasiliensis; (Btk) B. thuringiensis subsp. kurstaki.

Table 1. Median Lethal Concentration $\left(\mathrm{LC}_{50}\right)$ of Bacillus thuringiensis strains used against the termite Nasutitermes ehrhardti.

\begin{tabular}{lcccc}
\hline \multicolumn{1}{c}{ Isolate } & Time (days) & $\mathrm{LC}_{50}^{*}($ cells/ml) & Confidence interval (cells/ml) & Line equation \\
\hline B. thuringiensis subsp. & 3 & $4.70 \times 10^{9}$ & $3.9 \times 10^{6}-2.40 \times 10^{10}$ & $\mathrm{y}=0.12 \times+4.09$ \\
sooncheon & 5 & $6.62 \times 10^{7}$ & $2.0 \times 10^{5}-2.14 \times 10^{10}$ & $\mathrm{y}=0.13 \times 4.24$ \\
& 7 & $5.14 \times 10^{5}$ & $1.54 \times 10^{5}-1.82 \times 10^{6}$ & $\mathrm{y}=0.31 \times+3.85$ \\
\hline \multirow{2}{*}{ B. thuringiensis subsp. } & 3 & $3.08 \times 10^{6}$ & $1.24 \times 10^{5}-7.63 \times 10^{7}$ & $\mathrm{y}=0.24 \times+3.91$ \\
roskildiensis & 5 & $4.84 \times 10^{7}$ & $0.28 \times 10^{6}-8.22 \times 10^{8}$ & $\mathrm{y}=0.11 \times+4.35$ \\
\end{tabular}

* 60 insects per treatment. 


\section{ACKNOWLEDGMENTS}

The authors acknowledge with many thanks to M. M. Lecadet, from Institut Pasteur of Paris, for providing the strains of $B t$ and Luiz Roberto Fontes for the identification of the termites. Also thanks to CNPq for the fellowship to the first author.

\section{RESUMO}

\section{Susceptibilidade de Nasutitermes Ehrhardti (Isoptera: Termitidae) a subespécies de Bacillus thuringiensis}

O efeito de Bacillus thuringiensis sobre o cupim Nasutitermes ehrhardti (Isoptera, Termitidae) foi avaliado em condições laboratoriais. Ensaios in vivo com 55 cepas do patógeno, cedidas pelo Instituto Pasteur de Paris foram realizados em condições controladas onde sete destas foram consideradas patogênicas, sendo que $B$. thuringiensis subsp. yunnanensis, B. thuringiensis subsp. huazhongiensis, $B$. thuringiensis subsp. brasiliensis, B. thuringiensis subsp. colmeri, B. thuringiensis subsp. kurstaki, provocaram mortalidade inferior a $72 \%$ em isópteros. Os isolados $B$. thuringiensis subsp. sooncheon e B. thuringiensis subsp. roskildiensis causaram $100 \%$ de mortalidade ao sétimo dia após a aplicação das bactérias. As $\mathrm{CL}_{50}$ para B. thuringiensis subsp. sooncheon corresponderam a $47 \times 10^{8} ; 66,2 \times 10^{6}$ e $5,1 \times 10^{5}$ células/ $\mathrm{ml}$. Os valores correspondem aos três, cinco e sete dias, respectivamente. Para B. thuringiensis subsp. roskildiensis, no terceiro dia a $\mathrm{CL}_{50}$ correspondeu a $30,8 \times 10^{5}$, no quinto dia a $48,4 \times 10^{6}$ e no sétimo dia a $16,8 \times 10^{4}$ células $/ \mathrm{ml}$. Os dados obtidos mostram que as duas subespécies com maior patogenicidade podem ser estudadas, considerando o controle do cupim $N$. ehrhardti.

Palavras-chave: Bacillus thuringiensis, controle biológico, bactéria entomopatogênica, Nasutitermes ehrhardti, cupim.

\section{REFERENCES}

1. Alves, S.B. Controle Microbiano de Insetos. 2. ed. FEALQ, Piracicaba, 1998, 1163p.

2. Bravo, A.; R. Quintero. Importancia y potencial del Bacillus thuringiensis en el control de plagas. Oficina Regional de la F.A.O. para America Latina y el Caribe. Santiago, Chile, 1993.

3. Caetano, R.C.P.S.; Soares, M.M.N.; Dias, J.M.C.S.; Monnerat, R.G. Avaliação da patogenicidade de 41 estirpes de Bacillus thuringiensis contra Anticarsia gemmatalis, Spodoptera frugiperda e Tenebrio molitor. VI Simpósio de Controle Biológico, Rio de Janeiro, 1998, p.97.

4. Constantino, R. Morphology of the digestive tube of Macuxitermes triceratops and its phylogenetic implications (Isoptera, Termitidae, Nasutitermitinae). Sociobiology, 30: 225-230, 1997.

5. Cornelius, M.L.; Grace, J.K. Effect of two ant species (Hymenoptera: Formicidae) on the foraging and survival of the Formosan Subterranean Termite (Isoptera: Rhinotermitidae). Env. Entomol., 25: 85-89, 1996.

6. Cowie, R.H.; Logan, J.W.M.; Wood, T.G. Termite (Isoptera) damage and control in tropical forestry with special reference to Africa and Indo-Malasya: a review. Bull. Ent. Res., 79: 173-184, 1989.

7. Crickmore, N.; Zeigler, D.R.; Feitelson, J.; Schnepf, E.; Van Rie, J.; Lereclus, D.; Baum, J.; Dean, D.H. Revision of the nomenclature for the Bacillus thuringiensis pesticidal crystal proteins. Microbiol. Mol. Biol. Revs., 62: 807-813, 1998.

8. De Barjac H.; Frachon, E. Classification of Bacillus thuringiensis strains. Entomophaga, 35: 233-249, 1990.

9. Ebora, R.; Yadav, N.; Liu, J.; Sticklen, M. Genetic transformation of rice using modified Bacillus thuringiensis CryIA(b) gene for insect resistance. Seventh meeting of international program on rice biotechnology, Poster. Bali, Indonesia, 1994.

10. Ely, S. The engineering of plants to express Bacillus thuringiensis dendotoxins. Resistance to Bacillus thuringiensis and resistance management. In: Entwisle, P.F.; Cory, J.S.; Bailey, M.J.; Higgs, S. (eds). Bacillus thuringiensis, an Environmental Biopesticide: Theory and Practice. John Wiley \& Sons, New York, 1993, p.105-124.

11. Finney, D. Probit Analyses. Cambridge University Press, Cambridge, 1971, 333p.

12. Hernandez, J.L.L. Évaluation de la toxicité de Bacillus thuringiensis sur Spodoptera frugiperda. Entomophaga, 32: 163-171, 1988.

13. Honée, G.; Visser, B. The mode of action of Bacillus thuringiensis crystal proteins. Entomol. exp. appl., 69: 145-155, 1993.

14. Khan, K.; Jafri, R.H.; Ahmad, M. The pathogenicity and development of Bacillus thuringiensis in termites. Pak. J. Zool., 17: 201-209, 1985.

15. Khan, K.; Qaisra, F.; Jafri, R.H. Pathogenicity of locally discovered Bacillus thuringiensis strain to the termites Heterotermes indicola (Wasmann) and Microcerotermes championi (Snyder). Pakist. J. scient. Res., 29: 12-13, 1977.

16. Lambert, B.; Peferoen, M. Insecticidal promise of Bacillus thuringiensis. BioScience, 42: 112-122, 1992.

17. Vaeck, M.; Reynaets, A.; Höfte, H.; Jansens, S.; De Beucklerr, M.; Dean, C.; Zabeau, M.; Van Montagu, M.; Leemans, J. Transgenic plants protected from insect attack. Nature., 328: 33-37, 1987. 